\title{
Hot water usage profiling to improve geyser efficiency
}

\section{Quinton Catherine}

\section{Jacques Wheeler}

\section{Richardt Wilkinson}

Gerhard de Jager

Centre for Instrumentation Research, Faculty of Engineering, Cape Peninsula University of Technology, South Africa

\begin{abstract}
This paper presents an intelligent hot water cylinder (HWC) (referred to as geyser) usage profiling system to provide peak demand side management and improve HWC efficiency in a typical household. The study highlights current control topologies used to improve geyser efficiency, as well as the design of the final geyser controller. The system consists of a PIC microcontroller used to determine individually based hot water usage profiles of the user. The controller then regulates the temperature of the geyser according to the demand profile developed. From the results it is apparent that by controlling the geyser temperature and thereby heat loss, savings can be made.

Keywords: hot water profiling, microcontroller, geyser temperature control
\end{abstract}

\section{Introduction}

From 1994 to 2007, Eskom has seen a total electrical energy demand growth of $50 \%$ (Etzinger, 2008). In the first quarter of 2006, the first of many electricity power cuts started in South Africa as Eskom could not accommodate the increase in energy demand, especially during peak times. Since these power cuts, there has been an urgent need for improvement in energy efficiency (Eskom, 2006). As one measure taken towards solving the energy crisis, Eskom introduced demand side management (DSM).

The percentage of the population in South Africa with access to electricity has increased from $61.3 \%$ in 1995 to $84.9 \%$ in 2004 (Bredekamp, et al., 2006). Electricity usage by the domestic sector is substantial during peak demand times. Of all domestic devices the largest electric power usage is by hot water geysers. It therefore follows that by making use of sophisticated geyser controllers it should be possible to achieve a significant reduction in peak demand. Such controllers could in future also accommodate the interaction with auxiliary solar heaters to increase the efficiency of domestic hot water systems. This paper presents the development, design and testing of such a sophisticated geyser controller.

The structure of this paper is as follows: in part two, the importance of geyser control for demand side management is pointed out.

Part three reviews the present methods used for controlling geysers and in part four the design and implementation of a profiling geyser management system is described. The results obtained from field measurements are discussed in part five.

\section{Background}

\subsection{Demand side management/ Eskom}

Demand side management (DSM) involves the planning, implementing and monitoring of energy strategies to modify and reduce energy use (Bredekamp, et al., 2006) and traditionally focuses on technology roll-outs.

The DSM projects are aimed at three main sectors, namely residential, industrial $/$ mining, and commercial sectors. These projects aim to reduce the energy demand on Eskom during the peak times of the day. These peak periods are derived from 'Time of Use' (TOU) tables, which indicate the energy demand by users at various times of the day (Singh and Dekenah, 2006).

Figure 1 shows the energy load profile, in Gigawatts (GW), on Eskom during 2008. In the figure, the peak times are from 07:00 to 10:00 in the morning and from 18:00 to 20:00 in the evening. 
By reducing or shifting some of the peak demand to non-peak times, the load on Eskom during peak times can be reduced

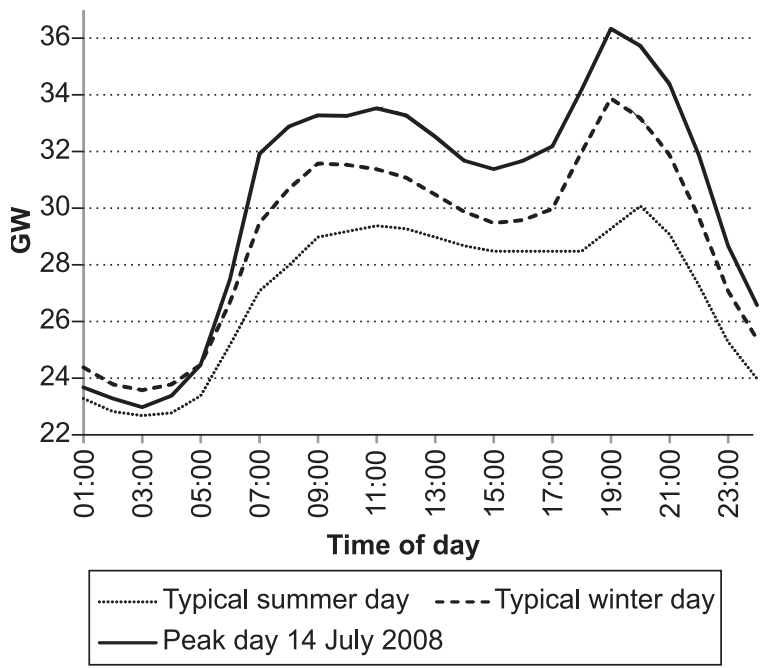

Figure 1: Energy profile in GW for 2008 Source: Eskom (2008)

The residential sector consumes around $17 \%$ of the total energy supplied by Eskom during nonpeak times but it can amount to around $30 \%$ of the total energy during peak times (Eskom, 2006).

Eskom has several DSM projects running, which aim to reduce the overall energy demand by 3000 MW by the year 2012. The long-term goal is to save 8000 MW by 2025 (Etzinger, 2008).

Table 1 shows a breakdown of the annual DSM targets, and how Eskom plans to achieve these savings. The table shows that the majority of the energy strategies are focused on the residential sector.

\begin{tabular}{|c|c|c|c|c|}
\hline \multicolumn{5}{|c|}{$\begin{array}{l}\text { Table 1: DSM four year plan } \\
\text { Source: Etzinger (2008) }\end{array}$} \\
\hline & $\begin{array}{c}2008 / \\
9\end{array}$ & $\begin{array}{c}2009 \\
/ 10\end{array}$ & $\begin{array}{c}2010 \\
/ 11\end{array}$ & $\begin{array}{c}2011 \\
/ 12\end{array}$ \\
\hline & $M W$ & $M W$ & $M W$ & $M W$ \\
\hline \multicolumn{5}{|l|}{ Residential } \\
\hline $\begin{array}{l}\text { Efficient lighting } \\
\text { (CFLs) }\end{array}$ & 484 & 50 & 100 & 634 \\
\hline - Solar water heating & 16 & 50 & 100 & 166 \\
\hline - Shower aerators & 5 & 10 & 20 & 35 \\
\hline $\begin{array}{l}\text { - Load reduction } \\
\text { (smart meter \& } \\
\text { TOU tariff) }\end{array}$ & 20 & 415 & 450 & 885 \\
\hline $\begin{array}{l}\text { - Geyser \& pipeline } \\
\text { insulation }\end{array}$ & 1 & 50 & 50 & 101 \\
\hline $\begin{array}{l}\text { - Household cooking } \\
\text { convert to gas }\end{array}$ & 36 & 123 & 130 & 289 \\
\hline Commercial & 60 & 35 & 40 & 135 \\
\hline Industrial & 131 & 70 & 57 & 258 \\
\hline Re-distribution & 47 & 30 & 20 & 97 \\
\hline Total & 800 & 833 & 967 & 2600 \\
\hline
\end{tabular}

Table 2 shows the breakdown of the electricity usage by a typical residential home. From this it can be seen that geysers are the major contributing factors to electricity consumption.

Table 2: Residential electricity consumption breakdown

Source: Harris, et al. (2008)

\begin{tabular}{lcc}
\hline Application & $k W h /$ year & $(\%)$ \\
\hline Water heating & 4259 & 36.1 \\
\hline Washing & 326 & 2.8 \\
\hline Cooking & 2447 & 20.7 \\
\hline Space heating & 404 & 3.4 \\
\hline Refrig/ freezer & 1829 & 15.5 \\
\hline Lights & 1766 & 15 \\
\hline Other appliances & 766 & 6.5 \\
\hline Total & 11797 & 100 \\
\hline
\end{tabular}

\subsection{Geysers}

Geysers are pressurised hot water containers, which are used to supply hot water to households. These containers are supplied via the mains supply (220 VAC). A thermostat is used as a control switch to regulate the temperature of the water by adjusting the heating duration of the element. When the temperature is close to the set-point on the thermostat (usually within $6^{\circ} \mathrm{C}$ ), the element is switched off. When the temperature of the geyser drops below the set point, the element is switched on and the water heated to the set point (Harris, et al., 2008).

There are two common sizes of geysers found in residential homes. A $3 \mathrm{~kW}, 150$ litre unit which can supply 2-3 people, and a $4 \mathrm{~kW}, 200$ litre unit which can supply 4-5 people (Monyane et al., 2008).

Geysers use electricity in one of two ways, either through hot water consumption or through standing losses (Delport, 2006).

- Hot water consumption in litres: When hot water is drawn from the geyser, cold water is used to replace the amount of water drawn. This results in a reduction in geyser temperature. Once below the set point, the thermostat closes, switching on the heating element. The higher the consumption, the more electricity required to reheat the cold water to the thermostat set point (Delport).

- Heat loss from the geyser: Standing/ heat loss from the geyser occurs when the heat of the water inside the geyser is dissipated through the casing, as well as through the outlet pipes. The higher the geyser temperature, and the colder the ambient temperature, the higher the rate at which the heat is lost (Delport, 2006).

\subsection{Standing losses}

Heat losses (or standing losses) incurred due to heat dissipation in the pipes and the geyser casing can 
be calculated using equation (1) (Delport, 2005):

$$
q_{\text {losses }}=\frac{\left(T_{h}-T_{\text {ambient }}\right)}{\frac{\Delta x}{k}+\frac{1}{h}}
$$

where:

$q_{\text {losses }}=$ heat loss in $\mathrm{W} / \mathrm{m}^{2}$

$T_{h}=$ water temperature inside the geyser $\left({ }^{\circ} \mathrm{C}\right)$

$T_{\text {ambient }}=$ air temperature outside geyser $\left({ }^{\circ} \mathrm{C}\right)$

$\Delta x=$ thickness of the insulating layer $(\mathrm{m})$

$k=$ thermal conductivity $(\mathrm{W} / \mathrm{m} . \mathrm{K})$

$h=$ surface heat temperature coefficient $\left(\mathrm{W} / \mathrm{m}^{2} . \mathrm{K}\right)$

For all calculations relating to $\mathrm{q}_{\text {losses }}$ in this paper, a standard 150 litre geyser was used. The thickness of the insulating layer, or wall thickness of the geyser, is taken as $0.035 \mathrm{~m}$, the conductivity as $0.055 \mathrm{~W} / \mathrm{m} . \mathrm{K}$ and the surface heat temperature coefficient as $6.3 \mathrm{~W} / \mathrm{m}^{2} . \mathrm{K}$ (Delport, 2005).

In order to calculate the total amount of energy dissipated by the geyser the $q_{\text {losses }}$ in $\mathrm{W} / \mathrm{m}^{2}$ was multiplied by the area of the cylinder.

Table 3 shows the summary of savings achievable through reduction in standing losses when comparing different thermostat settings to that of a thermostat set to $70^{\circ} \mathrm{C}$. The ambient temperature was taken at $20^{\circ} \mathrm{C}$ and the cost of electricity at $\mathrm{R} 0.4738$ per $\mathrm{kWh}$ as on the $14 / 11 / 08$. At $70^{\circ} \mathrm{C}$ the losses equal to $2.531 \mathrm{kWh} /$ day.

Table 3: Standing loss savings achievable for a single home

\begin{tabular}{lccc}
\hline $\begin{array}{l}\text { Thermo- } \\
\text { stat setting } \\
\left({ }^{\circ} \mathrm{C}\right)\end{array}$ & $\begin{array}{c}\text { Standing } \\
\text { losses } \\
(\mathrm{kWh}) / \text { day }\end{array}$ & $\begin{array}{c}\text { Savings } \\
(\mathrm{kWh}) \\
\text { month }\end{array}$ & $\begin{array}{c}\text { Savings } \\
/(\mathrm{R}) / \\
\text { month }\end{array}$ \\
\hline 65 & 2.278 & 7.84 & $\mathrm{R} 3.72$ \\
\hline 60 & 2.025 & 15.69 & $\mathrm{R} 7.43$ \\
\hline 55 & 1.772 & 23.53 & $\mathrm{R} 11.15$ \\
\hline 50 & 1.519 & 31.37 & $\mathrm{R} 14.86$ \\
\hline 45 & 1.266 & 39.22 & $\mathrm{R} 18.58$ \\
\hline 40 & 1.012 & 47.01 & $\mathrm{R} \mathrm{22.31}$ \\
\hline
\end{tabular}

In order to get an estimate of the typical standing heat loss, an example was taken from experimentally measured data.

Figure 2 shows the heating cycle of a typical geyser over a 24 hour period. Here no hot water was drawn in order to illustrate the standing losses. The geyser thermostat was set to $65^{\circ} \mathrm{C}$, and the average ambient temperature for the 24 hour period was $19^{\circ} \mathrm{C}$. The standing loss was calculated at $2.3 \mathrm{kWh}$ for the day. The average cut in time (interval between the element switching on) was measured at 6 hours and 14 minutes from Harris et al. (2007).

This research illustrates the fact that by reducing the geyser's temperature, savings can be made. In order to reduce the geyser temperature and supply the home owner with the required amount of hot water for the day, some sort of intelligence would have to be incorporated into the heating system.

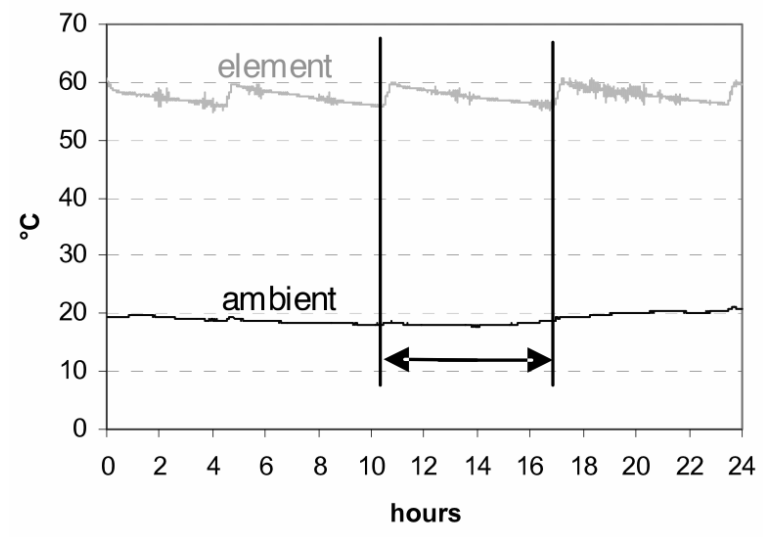

Figure 2: Heating cycle of geyser Source: Harris et al. (2007)

\section{Available techniques used to increase geyser efficiency}

Geyser blankets: A geyser blanket is placed over the geyser, and is used as an insulating layer, aiding the retention of heat. The results of Harris et al. (2007) and Bosman et al. (2006) showed that by placing a blanket over the geyser, the efficiency can be improved from between $18 \%$ to $27 \%$.

Dual element system: As the name suggests, the dual element system refers to two elements in one. For example, instead of having a $3 \mathrm{~kW}$ element, you have two $1.5 \mathrm{~kW}$ elements together, which form one design. Research (Delport, 2006) showed that minimum savings of $40 \mathrm{kWh}$ per month is possible, which results in a $13 \%$ total energy saving.

Ripple relays: The main purpose of the ripple relay is to shift the heating load of geysers out of peak demand times. This is done by switching off the geysers to a large number of homes for short periods during these peak demand times. Ripple relays provide a low level of control and are not individually based. This may lead to conditions where homeowners have no access to hot water (Beute, et al., 2006).

Hot water circulation pumps: The circulation pump is used to pump the hot water left in the pipes back into the geyser via the cold water pipes. This saves energy as it reduces the cut in time of the element (Calmeyer, 2003).

Programmable timers: Two devices available that provide a high level of control are the Electro Smart and Geyser Wise systems. Although these programmable timers offer a higher level of control than ripple relays, they still require manual setting of hot water usage times. If the user requires hot water at times other than that set on the user interface, the user has to change the settings manually using the interface module. 
Smart meters: At the moment South Africa is experimenting with two-way communication techniques used for measuring energy consumption, known as smart meters.

These smart meters generally refer to a type of advanced meter that identifies consumption in more detail than a conventional meter, and optionally communicates that information via some network back to the local utility for monitoring and billing purposes (Makwarela, 2007).

Based on the available techniques and results obtained by other researchers, it was decided to develop a system that would comprise of an intelligent controller, which would be able to develop a profile on the individual user/s hot water usage and implement itself without manual intervention. The aim of the profile is to reduce standing losses by reducing the geyser's temperature when hot water is not needed and to provide hot water when needed.

\section{Geyser controller}

\subsection{Layout}

In Figure 3, the layout of the controller is shown. As can be seen the controller consists of two types of sensors and a timer, the geyser temperature, the flow representing whether hot water is drawn and the time or length of hot water consumption.

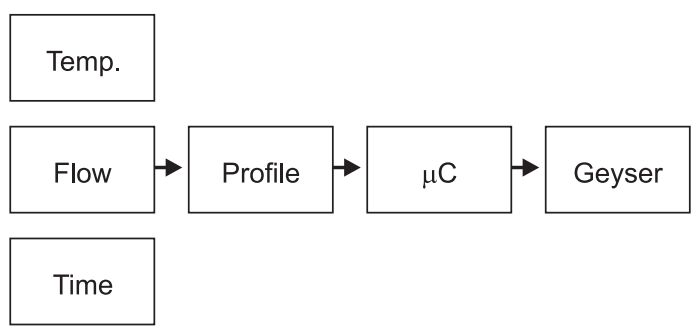

Figure 3: Conceptual block diagram of the controller

Using these three stimuli a profile for each household is deduced. This profile is stored in external memory via a PIC microcontroller. Once the profile has reached a certain confidence level, the microcontroller adjusts the temperature of the geyser according to the profile in its memory.

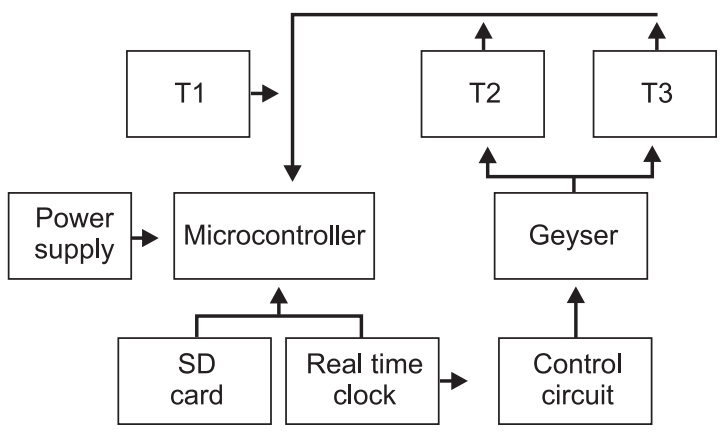

Figure 4: Block diagram of controller
The controller was designed using three temperature sensors as shown in Figure 4. T2 was coupled to the element plate, $\mathrm{T} 3$ to the outgoing pipe of the geyser, and T1 was mounted onboard and used to log the roof temperature needed for the $\mathrm{kWh}$ calculation.

\subsection{Profile}

In order to determine a hot water usage profile, the following sequence was followed:

- Determine frequency and time of usage of hot water;

- Allocate a temperature setting according to the frequency of use;

- Predict when hot water is going to be used based on gathered data;

- Refine the profile until acceptable accuracy is achieved;

- Implement the profile and,

- Continue refining profile after implementation.

As mentioned, the geyser temperature is regulat-

ed according to the profile gathered by the microcontroller. This profile consists of preset temperatures determined by the three stimuli. It was decided to have three service levels, or temperature settings. These settings were low $\left(45^{\circ} \mathrm{C}\right)$, medium $\left(55^{\circ} \mathrm{C}\right)$ and high $\left(65^{\circ} \mathrm{C}\right)$.

The low or standby setting was chosen at $45^{\circ} \mathrm{C}$. The reason for this was due to the disease known as Legionellosis. Legionellosis or Legionnaire's disease, is caused by bacteria known as Legionella pneumophila. This bacterium is considered very serious, as it is responsible for numerous fatalities worldwide every year. Legionella pneumophila proliferate in stagnant water from $20^{\circ} \mathrm{C}-45^{\circ} \mathrm{C}$, with the optimum temperature being between $32^{\circ} \mathrm{C}-37^{\circ} \mathrm{C}$. At temperatures below $20^{\circ} \mathrm{C}$ the bacteria remain dormant. When the water temperature is kept at $60^{\circ} \mathrm{C}$ the bacteria is killed after $20-30$ minutes and at temperatures above $70^{\circ} \mathrm{C}$ killed immediately (Ecosafe, n.d.).

A high setting of $65^{\circ} \mathrm{C}$ was chosen as previous research (Delport, 2005) showed that $64.3^{\circ} \mathrm{C}$ is the average temperature setting of thermostat controlled geysers. This setting was also chosen to accommodate high consumption, or large draw periods. This would typically be a shower, bath, etc. A medium setting was chosen at $55^{\circ} \mathrm{C}$. This was to accommodate short draw periods e.g. hand washes.

The controller would therefore build up the profile based on the frequency of hot water drawn, the higher the frequency for the particular time interval, the higher the temperature setting/ service level chosen.

\subsection{Time intervals}

Using a 150 litre $3 \mathrm{~kW}$ geyser as an example, the maximum time required to heat the water in a 
geyser from the low setting $\left(45^{\circ} \mathrm{C}\right)$ to the high setting $\left(65^{\circ} \mathrm{C}\right)$ was calculated using $(2)$ :

$$
\mathrm{P}=\frac{\text { Energy }(\mathrm{J})}{\text { Time }(\mathrm{s})}=\frac{(\mathrm{c} \times \mathrm{m} \times \Delta \mathrm{T})}{\mathrm{t}}
$$

where:

$P=$ power (3000 Watt)

$c=$ specific heat capacity $\left(\mathrm{J} \mathrm{kg}^{-1}{ }^{\circ} \mathrm{C}^{-1}=4187\right)$

$m=\operatorname{mass}(150 \mathrm{~kg})$

$\Delta T=$ change in temperature $\left(20^{\circ} \mathrm{C}\right)$

$t=$ time

When substituting the variables into the equation the time taken to heat the water from $45^{\circ} \mathrm{C}$ to $65^{\circ} \mathrm{C}$ using a $3 \mathrm{~kW}$ element would be \pm 1 hour 9 minutes. The power equation holds true for all sizes of geysers (Walser, 2002).

For this reason, 2 hour intervals were chosen. This then gives the controller adequate time to heat the geyser. A day profile therefore consisted of twelve 2 hour intervals. The frequency of hot water use was therefore determined for each of the twelve intervals and saved in a corresponding 2 hour interval variable.

\subsection{Service level control}

Each 2 hour slot records the actual service level or temperature setting and the service level prediction (SLP) made by the program. By comparing the actual service level calculated by the three stimuli and the service level prediction the accuracy of the system could be determined.

Each 2 hour slot contained twelve bytes of information used for data analysis and calculations. These bytes of information were time, day, date, month, year, roof temperature, day count, service level prediction (SLP), minutes of hot water used, frequency of occurrence $(F)$, for that 2 hour period, actual service level and percentage accuracy of the SLP. The formula used to calculate the actual service level based on previous information gathered can be seen in (3):

$$
\mathrm{F}=\frac{\mathrm{A}}{\mathrm{n}}
$$

where:

$A=$ Count of days that water was drawn within the specific 2 hour period

$n=$ Total number of day

This formula is based on the discrete uniform probability formula (Bertsekas, et al., 2002), and was used to calculate the service level fraction and expressed as a service level percentage (SL\%).

The SL\% was then grouped in either of the three service levels $\left(45^{\circ} \mathrm{C}, 55^{\circ} \mathrm{C}, 65^{\circ} \mathrm{C}\right)$ depending on the percentage value. The higher the SL\%, the higher the service level setting. Along with the service level for the 2 hour period a prediction is also saved. This prediction is made at the beginning of the 2 hour period, and is based on the previous accumulated service level value. The accuracy of the prediction versus the actual service level was also saved and determined as seen in Figure 5. The \%cnt2 is increased with every 2 hour interval. The accuracy of the prediction is therefore a ratio between how many correct predictions were made over the total number of predictions.

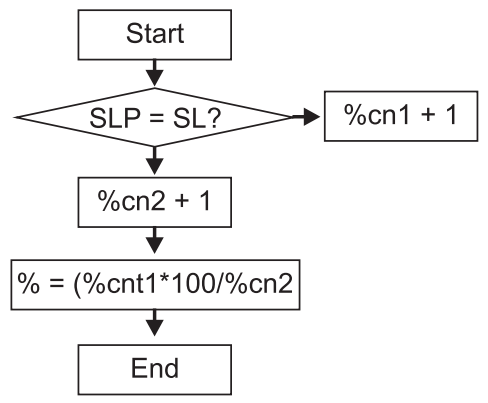

Figure 5: Flow diagram representing accuracy calculation

\section{Results}

Ten data loggers were built and installed into various homes with diverse demographic households to determine whether it was possible to develop an accurate hot water usage profile for the individual households.

Figure 6 shows the profile retrieved from the data loggers for Home1. As is shown, the home had frequent hot water draw periods for the interval 8:00 to $10: 00$ and therefore a high setting was assigned to that time interval.

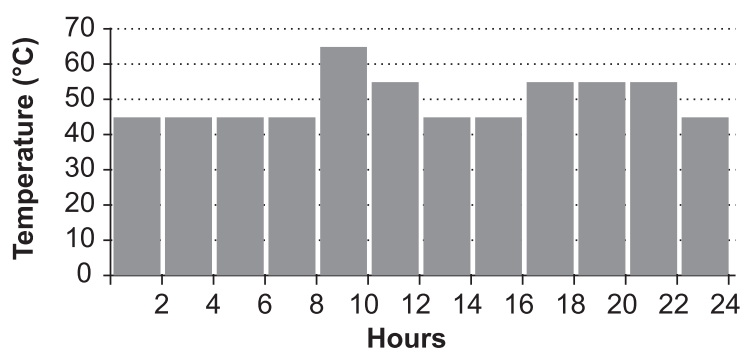

Figure 6: Profile gathered from home1

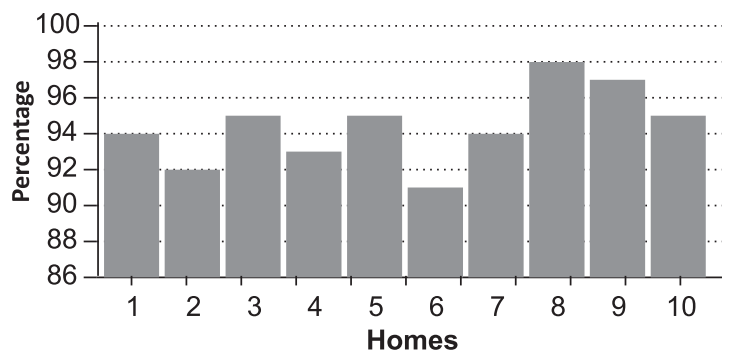

\section{Figure 7: Profile accuracies for the 10 homes} after 31 days

The system developed a profile for the individual house until the profile stabilized. The controller was then used to apply the profile while verifying usage pattern by determining how often the predic- 
tions were correct. Figure 7 represents the accuracies of all 10 homes of 31 days. A maximum accuracy of $98 \%$ was achieved and an average of $94.4 \%$ for the 10 homes.

\subsection{Energy savings}

To verify the savings made by the controller, a baseline profile was required of an unimplemented (thermostat controlled) system in order to determine the savings made by the profile controller. This would then give a before and after profile so comparisons can be made.

Table 4 represents the total $\mathrm{kWhs}$ used for an unimplemented geyser from $12^{\text {th }}$ March 09 to the $12^{\text {th }}$ April 09. This amounted to 238.3kWhs. At a cost of R 0.4738 per $\mathrm{kWh}$ the geysers electricity consumption amounted to R 112.91 .

Table 4: Total usage and cost analysis

\begin{tabular}{lcccc}
\hline Period & $\begin{array}{c}\text { Thermostat } \\
\text { Setting }\end{array}$ & $\begin{array}{c}k W h \\
\text { used }\end{array}$ & $\begin{array}{c}\text { Minutes } \\
\text { used }\end{array}$ & Cost \\
\hline $12 / 03 / 09$ & 65 & 238.3 & 680 & R112.91 \\
$-12 / 04 / 09$ & & & & \\
\hline
\end{tabular}

Using the average geyser and roof temperatures measured for the month, the amount of standing losses was calculated. This amounted to $57 \mathrm{kWhs}$ and at a cost of R 27.17 for the month. The standing losses therefore contributed to $24 \%$ of the total energy consumed by the geyser.

By subtracting the standing losses from the total energy consumed the amount of actual kWhs used for water consumption by the geyser was calculated at $180.96 \mathrm{kWhs}$ and at a cost of R 85.74.

Table 5 shows the comparison between the average temperatures of the unimplemented and implemented systems over a month period. The profile controller reduced the average temperature of the geyser by almost $10^{\circ} \mathrm{C}$, while at the same time still providing hot water when required, as per the profile.

Table 5: Average geyser temperature comparison

\begin{tabular}{lcc}
\hline $\begin{array}{l}\text { Unimplemented } \\
\text { system (Before) }\end{array}$ & $\begin{array}{c}\text { Implemented } \\
\text { system (After) }\end{array}$ & Difference \\
\hline $61.87^{\circ} \mathrm{C}$ & $52.35^{\circ} \mathrm{C}$ & $9.52^{\circ} \mathrm{C}$ \\
\hline
\end{tabular}

Table 6 shows the comparison between the energy usage of the conventional thermostat controlled geyser and that of the profile controlled geyser. Both systems had a total hot water draw of 680 minutes for the month period.

A saving of $R 35.50$ was made in the month. As a result, the total energy required for hot water for the ten houses was reduced by $31.5 \%$.
Table 6: Usage comparison and savings

\begin{tabular}{lllll}
$\begin{array}{l}\text { Usage } \\
\text { (thermostat } \\
\text { controlled) } \\
\text { (kWh) }\end{array}$ & $\begin{array}{c}\text { Usage Difference } \\
\text { (profile } \\
\text { controlled) } \\
\text { (kWh) }\end{array}$ & $\begin{array}{c}\text { Saving } \\
(\%)\end{array}$ & $\begin{array}{c}\text { Saving } \\
\text { (Rands) }\end{array}$ \\
\hline 238.29 & 163.27 & 75.02 & 31.5 & 35.55 \\
\hline
\end{tabular}

$$
\begin{array}{ll}
\text { Controller cost } & = \pm \mathrm{R} 200 \\
\text { Labour } & =\mathrm{R} 285 \\
\text { Savings } & =\mathrm{R} 35.55 \\
\text { Payback period } & =\mathrm{R} 485 / \mathrm{R} 35.55 \\
& = \pm 14 \text { months }
\end{array}
$$

\section{Conclusion}

From the results it was shown that the average temperature of the geyser was reduced by almost $10^{\circ} \mathrm{C}$ and at the same time still providing the user with hot water when required. By reducing the average temperature, not only were the standing losses reduced, but the total energy consumption of the geyser was reduced by $31.5 \%$. This amounted to a $\mathrm{R} 35.55$ saving for the month. In conclusion, the profile based controller reduced the energy consumption of the geyser.

As the results have shown, the profile based controller has a payback period of 14 months, making the controller a really efficient and inexpensive form of improving energy efficiency in the residential sector. With the increase in electricity tariffs the payback period of the controller would decrease.

\section{References}

Bertsekas, D.P. \& Tsitsiklis, J.N. (2002). Introduction to probability. Athena Scientific. 2002, pp.11.

Beute, N. \& Delport, G.J. (2006). An Historic Overview of Controlling Domestic Water Heating. Proceedings of the 14th Domestic Use of Energy Conference, Cape Town, April 2006, Cape Peninsula University of Technology: pp. 41-46.

Bosman, I. E., Grobler, L. J. \& Dalgleish, A. Z. (2006). Determination of the impact on the standing losses of installing blankets to electric hot water heaters in South Africa. Journal of Energy in Southern Africa, 17(2): 57-64, May.

Bredekamp, A.J., Uken, E-A. \& Borrill, L. ((2006)). Standby power consumption of domestic appliances in South Africa. Proceedings of the $14^{\text {th }}$ Domestic Use of Energy Conference, Cape Town, April 2006, Cape Peninsula University of Technology: pp. 211-216.

Calmeyer, J. E. (2003). A basic model of a residential hot water system using a circulation pump to minimise standing losses in piping. Proceedings of the $11^{\text {th }}$ Domestic Use of Energy Conference, Cape Town, April 2003, Cape Peninsula University of Technology: pp. $123-128$.

Delport, G.J. (2005). The Geyser Gadgets that work/ do not work. Proceedings of the $13^{\text {th }}$ Domestic Use of Energy Conference, Cape Town, March 2005, Cape Peninsula University of Technology: pp. 139 - 144. 
Delport, G.J. (2006). Achieving Energy Efficiency for Hot Water Cylinders (Geysers) with the new Dual Element System. Proceedings of the $14^{\text {th }}$ Domestic Use of Energy Conference, Cape Town, April 2006, Cape Peninsula University of Technology: pp. 57-61.

Ecosafe. n.d. Leionella. www.ecosafe.co.za/legionella. html, (05 June 2008).

Eskom (2006). Energy Efficiency and Demand Side Management in South Africa. DSM Case study. www.ESKOM.co.za/live/content.php?Item_ID $=2787$, (05 June 2008).

Eskom (2008). Eskom Profile. Annual Report 2008. www.ESKOM.co.za/annreport08/ar_2008/downloads.htm, (10 January 2009).

Etzinger, A. (2008). Crunch time: DSM to the rescue. $16^{\text {th }}$ Domestic Use of Energy Conference. active. cput.ac.za/energy/public/index.asp?pageid $=54$ 5, (10 January 2009).

Harris, A., Kilfoil, M. \& Uken, E-A. (2007). Domestic energy savings with geyser blankets. Proceedings of the $15^{\text {th }}$ Domestic Use of Energy Conference, Cape Town, 2007, Cape Peninsula University of Technology: pp. 153-158.

Harris, A, Kilfoil, M. \& Uken, E-A. (2008). Options for residential water heating. Proceedings of the $16^{\text {th }}$ Domestic Use of Energy Conference, Cape Town, 2008, Cape Peninsula University of Technology: pp. 141-148.

Makwarela, M. E. (2007). Introducing Smart Meters into South African Utilities. Proceedings of the 11th Revenue Protection Conference, George, $19^{\text {th }} \& 20^{\text {th }}$ July 2007, Fancourt.

Monyane, D.W., Khan, I. \& Uken, E-A. (2008). Measured energy savings on a domestic solar/electric hot-water heating system. Proceedings of the $16^{\text {th }}$ Domestic Use of Energy Conference, Cape Town, 2008, Cape Peninsula University of Technology: pp. 105-109.

Singh, V. \& Dekenah, M. (2006). The pilot testing and findings of the residential time-of-use tariff (Homeflex) project from an Eskom perspective. AMEU Conference, Johannesburg, $16^{\text {th }}-18^{\text {th }}$ October, www.ameu.co.za/ events/convention2006/presentationsameu06/, (05 June 2008).

Walser, C. P. (2002). Electrical Engineering 1. Cape Technikon. Revised Edition 4, January 2002.

Received 14 October 2009; revised 26 July 2011 